\title{
DESKRIPSI KEMAMPUAN BERPIKIR KRITIS SISWA MELALUI PEMBELAJARAN DARING PADA MATERI SEGI EMPAT
}

\author{
Perry Zakaria $^{1}$, Nurwan ${ }^{2}$, Frendy Dermawan Silalahi ${ }^{3 *}$ \\ 1,2,3 Jurusan Matematika, Universitas Negeri Gorontalo, Bone Bolango 96119, Indonesia \\ *Penulis Korespondensi. Email: frendy.dermawan@gmail.com
}

\begin{abstract}
Abstrak
Penelitian ini bertujuan untuk mendeskripsikan kemampuan berpikir kritis siswa pada pembelajaran yang dilaksanakan secara daring. Penelitian dilaksanakan di kelas VIII SMP Negeri Widyakrama yang melibatkan 23 siswa sebagai subjek penelitian. Pengumpulan data diperoleh dari instrumen tes uraian yang telah divalidasi. Instrumen tes tersebut digunakan untuk menjaring data kemampuan berpikir kritis matematis siswa dengan indikator (a) identifikasi masalah (b) analisis, (c) sintesis, dan (d) menarik kesimpulan. Hasil penelitian menunjukkan bahwa kemampuan berpikir kritis siswa yang dilaksanakan melalui pembelajaran daring di SMP Negeri Widyakrama berada pada kategori sedang. Hal ini ditunjukkan dengan klasifikasi kemampuan berpikir kritis dari 23 responden. Hanya terdapat 5 siswa yang berada pada kategori tinggi, 14 siswa berada pada kategori sedang, dan 4 siswa berada pada kategori rendah.
\end{abstract}

Kata Kunci: Kemampuan Berpikir Kritis; Pembelajaran Daring; Segi Empat

\begin{abstract}
This research is a descriptive study that aims to describe students' critical thinking abilities carried out by online learning. This research was conducted in class VIII SMP Negeri Widyakrama involving 23 students as research subjects. Data collection was obtained from validated essay test instruments. The test instrument was used to collect data on students' mathematical critical thinking abilities with indicators (a) problem identification (b) analysis, (c) synthesis, and (d) drawing conclusions. The results showed that students' critical thinking abilities implemented through online learning at Widyakrama State Middle School were in the medium category. This is shown based on the classification of critical thinking abilities of 23 respondents. There are only 5 students who are in the high category, 14 students are in the medium category, and 4 other students are in a low category.
\end{abstract}

Keywords: Critical Thinking Abilities; Online Learning; Rectangular

\section{Pendahuluan}

Adanya dampak langsung dari munculnya virus covid-19 mengakibatkan aktivitas yang melibatkan perkumpulan orang banyak mulai dibatasi seperti bersekolah, bekerja, beribadah dan lain sebagainya. Pemerintah sudah mengimbau untuk bekerja, belajar, dan beribadah dari rumah untuk menekan angka yang terpapar covid-19. Kementrian pendidikan mengeluarkan surat edaran No.4 tentang pelaksanaan pendidikan atau kegiatan pembelajaran disekolah-sekolah dihentikan untuk sementara karena termasuk kegiatan yang melibatkan banyak orang [1]. Hal ini menuntut peserta didik untuk belajar dari rumah menggunakan jaringan internet. Pembelajaran yang awalnya bersifat pembelajaran konvensional kini dialihkan dalam pembelajaran daring.

Dengan beralihnya pembelajaran konvensional menjadi pembelajaran daring secara mendadak mengakibatkan timbulnya beberapa masalah yang dihadapi guru dan peserta didik, terlebih lagi pembelajaran daring belum pernah diterapkan oleh guru pembelajaran di sekolah. Salah satu pelajaran yang akan mengalami masalah dalam proses pembelajaran daring adalah matematika, karena sebagian besar peserta didik menganggap pelajaran matematika adalah 
pelajaran yang membosankan dan materi yang sangat sulit. Maulana [2] mengatakan bahwa keunikan dan kompleksitas unsur matematika mengharuskan para pembelajar matematika di dalam kelas mampu berpikir kritis dalam mempelajari matematika. Kemampuan berpikir kritis siswa dalam pembelajaran matematika sangatlah penting, hal ini sependapat dengan Sumarmo, dkk [3] yang mengatakan kemampuan berpikir kritis siswa dalam pembelajaran matematika sangat diperlukan untuk memahami dan memecahkan suatu permasalahan atau soal matematika yang membutuhkan penalaran, analisis, evaluasi dan interpretasi pikiran. Hal ini menunjukkan bahwa berpikir kritis merupakan suatu aspek yang sangat dibutuhkan dalam pembelajaran khususnya dalam pembelajaran matematika. Sejalan dengan Permendukbud Nomor 20 Tahun 2016 tentang Standar Kompetensi Lulusan Pendidikan Dasar dan Menengah, pada dimensi keterampilan siswa diharapkan memiliki keterampilan berpikir kritis [4]. Sehingga apabila pelajaran matematika diajarkan menggunakan pembelajaran daring, akan ada kemungkinan beberapa peserta didik yang tidak paham dengan penjelasan guru pembelajaran daring, khususnya dalam materi segi empat, karena dalam pelajaran segi empat dibutuhkan cara terbaik untuk menyampaikan berbagai konsep yang diajarkan sehingga siswa dapat menggunakan dan mengingat lebih lama dari konsep tersebut.

Pembelajaran daring menjadi salah satu alternatif yang bisa digunakan dalam proses pembelajaran saat ini. Perkembangan zaman yang semakin canggih memungkinkan pengajar untuk dapat menjalankan tugasnya tanpa harus bertemu secara langsung dengan pelajar di suatu tempat yang sama yaitu melalui pembelajaran daring. Sependapat dengan Sadikin [5] yang mengatakan pembelajaran daring memiliki flexibilitas dalam pelaksanaannya dan juga mampu mendorong munculnya kemandirian belajar dan memotivasi untuk lebih aktif dalam belajar. Seperti pendapat Hulukati [6] pembelajaran daring adalah sistem belajar yang terbuka dan tersebar dengan menggunakan perangkat pedagogi (alat bantu pendidikan), yang dimungkinkan melalui internet dan teknologi berbasis jaringan untuk memfasilitasi pembentukan proses belajar dan pengetahuan melalui aksi dan interaksi yang berarti. Walaupun situasi dan kondisi saat ini yang tidak memungkinkan untuk belajar di sekolah, pembelajaran daring yang bisa digunakan dalam pembelajaran [7]. Berbagai alternatif pembelajaran daring telah banyak dikembangkan sejak zaman pandemi memaksa pembelajaran berlangsung dari rumah, diantaranya dapat ditemukan pada [8][10]. Apalagi sekarang ini banyak materi yang dapat diakses oleh peserta didik melalui jaringan internet, misalnya video pembelajaran yang dapat diakses melalui youtube ataupun beberapa aplikasi pembelajaran yang sudah ada saat ini, yang dapat memberikan kemudahan dalam transfer informasi pada berbagai situasi dan kondisi [11]. Bisa dikatakan penunjang keberhasilan pembelajaran daring tidak lain adalah kesiapan pendidik dan peserta didik dari segi mental, pemanfaatan teknologi dan informasi yang berkesesuaian, serta sumber belajar yang relevan. Namun tidak dapat di pungkiri, teknik mengajar guru merupakan bagian yang menjadi perhatian penting dalam keberhasilan pembelajaran daring, sebab tugas seorang guru bukan hanya terfokus pada penyampaian ilmu saja, melainkan bagaimana seorang guru dapat membentuk karakter, kreativitas, rasa ingin tahu dan sifat kepribadian serta kemampuan berpikir kritis siswa meskipun bukan dalam konteks pembelajaran tatap muka. Hal ini menjadi tantangan terbesar bagi semua pihak terutama guru agar bisa menyampaikan materi matematika secara kreatif sehingga peserta didik bisa tertarik dengan materi yang akan dipelajari dan juga memahami materi yang diajarkan tersebut.

Whatsapp merupakan media komunikasi yang familiar bagi semua kalangan termasuk juga guru dan peserta didik, sehingga whatsapp bisa dijadikan sebagai sarana pembelajaran daring seperti halnya didalam kelas. Hal ini dikarenakan kelengkapan fitur-fitur whatsapp yang dapat menunjang proses pembelajaran seperti mengirim gambar, dokumen, audio, maupun video. Selain itu guru dan peserta didik juga dapat saling berdiskusi atau membagikan informasi dalam whatsapp group. WhatsApp merupakan salah satu media komunikasi yang sangat popular yang digunakan saat ini, whatsapp merupakan salah satu aplikasi yang digunakan untuk melakukan percakapan baik menggunakan teks, suara, maupun video. Menurut Kusuma [12] Whatsapp dalam penggunaannya sebagai media chat digital yang mencakup pesan teks, gambar, video, dan dapat untuk menelpon menjadi satu kesatuan yang lengkap untuk membantu masyarakat dalam menjalin komunikasi di 
seluruh belahan dunia. Pembelajaran daring di SMP Negeri Widyakrama menggunakan media whatsapp karena merupakan media komunikasi yang paling populer sebagai media komunikasi. Namun belum kita ketahui bagaimana penggunaan pembelajaran daring dalam hal ini adalah penggunaan whatsapp group dalam pembelajaran matematika sebagai solusi dari pembelajaran daring. Hal inilah yang perlu diketahui sejauh mana dampak whatsapp group dalam pembelajaran matematika di masa pandemi ini. Aplikasi whatsapp ini dilengkapi dengan berbagai pilihan yang mendukung seperti adanya new group, new broadcast, whatsapp web, starred messages dan setings, fitur lengkap yang tersedia di aplikasi whatsapp membuat penggunanya semakin meningkat pesat, berbagai pilihan yang tersedia di whatsapp tersebut ada salah satunya bernama new group yang belakangan ini banyak digunakan para pelajar, mahasiswa dan dosen sebagai media komunikasi yang terhalang oleh jarak yang disebut WA group.

Beberapa hasil penelitian menunjukkan bahwa kemampuan berpikir kritis siswa sebelum menggunakan pembelajaran daring menunjukkan hasil yang baik, seperti yang dilakukan oleh Fithriyah [13] dan Pertiwi [14]. Penelitian Tresnawati [15] juga menunjukkan kemampuan berpikir kritis matematis dan kepercayaan diri siswa juga menunjukkan hasil yang baik sebelum pandemi covid-19 ini. Dengan adanya kebijakan pembelajaran online maka penelitian merujuk pada pembahasan yang berkaitan dengan pembelajaran online. Problematika pembelajaran daring di masa pandemi covid-19 seperti yang ditemukan pada Zakaria [16] bahwa permasalahan dari guru berupa lemahnya penguasaan IT dan terbatasnya akses pengawasan peserta didik serta keterbatasan akses jaringan internet menjadi kendala besar dalam pembelajaran daring. Namun penggunaan aplikasi whatsapp bisa efektif dalam sebuah pembelajaran dikarenakan media whatsapp sedang populer di masyarakat [17].

Pada artikel ini dibahas tentang kemampuan berpikir kritis siswa yang menerima pembelajaran secara daring. Penelitian dilakukan untuk mengetahui tingkatan kemampuan berpikir kritis matematis siswa dengan mengelompokkannya berdasarkan klasifikasinya. Hasil klasifikasi kemampuan berpikir kritis siswa dapat menjadi acuan bagi guru untuk melihat sejauh mana peserta didik mampu untuk mengembangkan kemampuan berpikir kritis mereka dalam pembelajaran daring dan dapat menjadi pembanding terhadap kemampuan berpikir kritis siswa dalam pembelajaran luring.

\section{Metode Penelitian}

Metode penelitian berisi penguraian kemampuan berpikir kritis siswa yang menggunakan media whatsapp sebagai pembelajaran daring. Penelitian ini menggunakan metode penelitian deskriptif untuk mendeskripsikan kemampuan berpikir kritis siwa yang dilaksanakan melalui pembelajaran daring. Penelitian ini melibatkan 23 orang siswa sebagai sampel penelitian yang ditentukan menggunakan teknik purposive sampling. Data yang digunakan adalah data kemampuan berpikir kritis siswa yang diperoleh melalui tes essay. Data diperoleh dengan cara memberikan instrumen tes yang berbentuk tes essay pada materi segi empat. Sebelum tes essay kemampuan berpikir kritis matematis siswa disebarkan, beberapa instrument tersebut diuji validitas dan reliabilitasnya [18]. Kemudian data yang diperoleh dianalisis menggunakan analisis persentase. Untuk mengetahui persentase hasil belajar digunakan rumus berikut:

$$
\text { Nilai Perolehan }=\frac{\text { Jumlah Skor Perolehan }}{\text { Skor Maksimal }} \times 100 \%
$$

Untuk mengetahui tingkat kempuan berpikir kritis masing-masing siswa, dilakukan pengkategorian data kemampuan berpikir kritis siswa. Kriteria pengkategorian mengacu pada Tabel 1 dan Tabel 2. 
Tabel 1. Kategori Kemampuan Berpikir Kritis

\begin{tabular}{cc}
\hline Kriteria & Nilai \\
\hline Tinggi & Nilai $\geq \bar{x}+S D$ \\
Sedang & $\bar{x}-S D \leq$ Nilai $\bar{x}+S D$ \\
Rendah & Nilai $<\bar{x}-S D$ \\
\hline
\end{tabular}

Tabel 2. Persentase Kemampuan Berpikir Kritis

\begin{tabular}{cc}
\hline Presentase $(\%)$ & Kategori \\
\hline $69-100$ & Tinggi \\
$45-68$ & Sedang \\
$0-44$ & Rendah \\
\hline
\end{tabular}

\section{Hasil dan Pembahasan}

\subsection{Hasil}

Hasil penelitian yang ditunjukan melalui instrumen tes berpikir kritis matematis siswa pada materi segi empat yang dilaksanakan dengan pembelajaran daring di kelas VIII SMP Negeri Widyakrama berdasarkan indikator kemampuan berpikir kritis ditunjukkan pada Tabel 3.

Tabel 3. Deskripsi Kemampuan Berpikir Kritis Tiap Indikator

\begin{tabular}{cccccc}
\hline No. Soal & $\begin{array}{c}\text { Identifikasi } \\
\text { Masalah }\end{array}$ & Analisis & Sintesis & $\begin{array}{c}\text { Menarik } \\
\text { Kesimpulan }\end{array}$ & Skor Total \\
\hline 1 & 60 & 59 & 53 & 44 & 216 \\
2 & 54 & 51 & 45 & 40 & 190 \\
3 & 48 & 45 & 43 & 37 & 173 \\
4 & 57 & 46 & 44 & 41 & 188 \\
5 & 61 & 49 & 45 & 38 & 193 \\
6 & 46 & 47 & 44 & 36 & 173 \\
\hline Jumlah & 326 & 297 & 274 & 236 & 1133 \\
\hline Persentase & $78,74 \%$ & $71,74 \%$ & $66,18 \%$ & $57,00 \%$ & $68,42 \%$ \\
\hline
\end{tabular}

Berdasarkan data pada Tabel 3, diketahui presentasi capaian berdasarkan indikator kemampuan berpikir kritis ebagai berikut:

1) Indikator 1: Identifikasi Masalah

Dari 23 siswa total skor yang diperoleh sebanyak 326 dari total skor ideal 414 dengan capaian presentase $78,74 \%$.

2) Indikator 2: Analisis

Dari 23 siswa skor yang diperoleh yaitu 319 dari total skor ideal 414 dengan capaian presentase $77,05 \%$.

3) Indikator 3: Sintesis

Dari 23 siswa skor total yang diperoleh 274 dari total skor ideal 414 dengan capaian persentase $66,18 \%$

4) Indikator 4: Menarik kesimpulan

Dari 23 siswa skor total yang yang diperoleh ialah 236 dari total skor ideal 414 dengan capaian presentase $57,00 \%$.

Dari Tabel 3 juga ditunjukkan bahwa jumlah skor yang diperoleh seluruh siswa untuk semua nomor soal terhadap indikator berpikir kritis sebesar 1156 dari total skor ideal 1133 dari total skor ideal 1656 atau berada pada tingkat presentase 68,42\%, dengan indikator yang paling banyak dilakukan siswa secara keseluruhan dari masing-masing butir soal adalah identifikasi masalah yaitu 
sebesar 78,74\%, kemudian disusul dengan indikator analisis yaitu sebesar $71,74 \%$, selanjutnya indikator sintesis yaitu 66,18\% dan menarik kesimpulan yaitu sebesar 57,00\%

Tingkat kemampuan berpikir kritis siswa yang dilakukan untuk semua butir soal yang ditinjau berdasarkan kelompok kategori terhadap setiap indikator berpikir kritis disajikan dalam Tabel 4.

Tabel 4. Deskripsi Kemampuan berpikir Kritis Berdasarkan Kategori

\begin{tabular}{|c|c|c|c|c|c|c|}
\hline \multirow[t]{2}{*}{ Kategori } & \multirow[t]{2}{*}{ Subjek } & \multicolumn{4}{|c|}{ Indikator } & \multirow{2}{*}{$\begin{array}{l}\text { Total } \\
\text { Skor }\end{array}$} \\
\hline & & $\begin{array}{c}\text { Identifikasi } \\
\text { Masalah }\end{array}$ & Analisis & Sintesis & $\begin{array}{l}\text { Menarik } \\
\text { Kesimpulan }\end{array}$ & \\
\hline Tinggi & 5 & 70 & 78 & 85 & 80 & 313 \\
\hline Sedang & 14 & 211 & 182 & 161 & 136 & 690 \\
\hline Rendah & 4 & 45 & 37 & 28 & 20 & 130 \\
\hline Total & 23 & 326 & 297 & 274 & 236 & 1133 \\
\hline
\end{tabular}

Berdasarkan Tabel 4, digambarkan kemampuan berpikir kritir berdasarkan kategori tinggi, sedang, dan rendah.

1) Kategori Tinggi

Berdasarkan hasil skor yang diperoleh siswa, dari jumlah responden 23 terdapat 5 siswa yang berada pada kategori tinggi. Total skor yang diperoleh siswa tersebut 313 yang terdiri atas indikator identifikasi masalah 70, pada indikator analisis 78, pada indikator sintesis sebesar 85, dan pada indikator menarik kesimpulan 80 .

2) Kategori Sedang

Berdasarkan hasil skor yang diperoleh dari 23 siswa terdapat 14 siswa berada pada kategori sedang. Dari 14 siswa, skor yang diperoleh sebesar 690, dimana skor tersebut terbagi atas 4 indikator, pada indikator identifikasi masalah sebesar 211, pada indikator analisis sebesar 182, pada indakor sintesis sebesar 161, dan indikator menarik kesimpulan sebesar 136.

3) Kategori Rendah

Berdasarkan perolehan skor dari 23 siswa terdapat 4 siswa berada pada kategori rendah. Dari 4 siswa skor yang diperoleh sebesar 130. Dimana skor tersebut terbagi atas 4 indikator, pada indikator identifikasi masalah sebesar 45, pada indikator analisis sebesar 37, sedangkan indikator sintesis sebesar 28, dan indikator menarik kesimpulan terdapat 20.

\subsection{Pembahasan}

Kemampuan berpikir kritis siswa pada materi segi empat yang dilaksanakan dengan pembelajaran daring di kelas VIII SMP Negeri Widyakrama tergolong dalam kategori sedang, hal ini berarti dalam penyelesaian soal, sudah banyak siswa yang memenuhi semua indikator namun ada pula siswa yang belum memenuhi keseluruhan indikator kemampuan berpikir kritis pada materi segi empat. Berdasarkan hasil dan pengkategorian tersebut maka akan dijelaskan karakteristik masing-masing kategori ditinjau dari indikator kemampuan berpikir kritis matematis yaitu sebagai berikut.

\section{1) Kategori Tinggi}

Berdasarkan analisis data dari hasil penelitian, bahwa secara keseluruhan terdapat 5 siswa yang berada pada kategori tinggi. Siswa yang berada pada kategori tinggi artinya siswa sudah memenuhi indikator berpikir kritis sesuai yang telah disebutkan sebelumnya. Subjek dengan predikat tinggi dapat dilihat dari hasil tes yakni mampu mengidentifikasi unsur-unsur yang diketahui dan ditanyakan dalam soal, mampu menguraiakan pernyatan-pernyataan, pertanyaan dan konsep dari soal yang diberikan dengan benar tetapi masih kurang lengkap, mampu menyelesaikan permasalahan dengan mengaitkan unsur pengetahuan yang ada sehingga memperoleh jawaban yang benar, selain itu subjek juga mampu menarik kesimpulan dengan baik. 


\section{2) Kategori Sedang}

Berdasarkan analisis data dari hasil penelitian, bahwa secara keseluruhan dari 23 responden terdapat 14 siswa yang berada pada kategori sedang. Artinya sebagian lebih siswa sudah mampu mengerjakan soal namun belum dapat memenuhi capaian indikator kemampuan berpikir kritis atau sebagian lebih siswa tersebut sudah dapat memenuhi keempat indikator berpikir kritis, namun skor yang diperoleh pada keseluruhan indikator berbeda-beda sehingga belum mampu mencapai nilai standar pada kategori tinggi. Hal ini sependapat dengan Syahbana [19] yaitu dengan kemampuan siswa dalam mengerjakan soal, dimana siswa tersebut sudah mampu mengidentifikasi unsur yang diketahui dan ditanyakan dalam soal walaupun masih ada juga beberapa siswa yang keliru, siswa juga masih ada yang kesulitan dalam menguraikan komponen yang diperlukan sebelum menyelesaikan soal yang diberikan, dan skor siswa pada indikator menarik kesimpulan masih rendah yang mungkin menyebabkan siswa berada pada kategori sedang

3) Kategori Rendah

Berdasarkan analisis data dari hasil penelitian, bahwa secara keseluruhan dari 23 responden terdapat 4 siswa berada pada kategori rendah. Hal ini dapat dilihat sebagian kecil siswa tidak mampu menyelesaikan masalah namun mereka menyelesaikan soal tersebut dengan menggunakan cara yang mereka ketahui dan ada pula yang tidak memberikan solusi jawaban dibeberapa soal. Siswa yang berada pada kategori rendah ada yang sudah memenuhi indikator kemampuan berpikir kritis matematis, ada pula siswa yang hanya memenuhi 2 dan 3 indikator tersebut. Akan tetapi skor yang mereka peroleh secara keseluruhan pada indikator yang ditentukan masih tergolong minim.

Dengan demikian dapat diketahui dengan jelas bahwa tingkat kemampuan berpikir kritis pada materi segi empat di kelas VIII SMP Negeri Widyakrama berada pada kategori sedang. Dimana siswa mampu mencapi skor tertinggi dari indikator identifikasi masalah dan untuk indikator menarik kesimpulan masih rendah. Siswa cenderung terfokus dalam menyelesaikan masalah untuk menemukan jawab yang tepat dan mengabaikan hal lain seperti menarik kesimpulan.

Siswa keliru dalam menyelesaikan soal-soal kemampuan berpikir kritis dikarenakan siswa kurang teliti dalam tahapan pengerjaan jawaban. Hal lain yang menyebabkan kurang maksimalnya hasil test kemampuan berpikir kritis matematis siswa, yaitu dikarenakan siswa kurang mampu memahami materi pembelajaran dalam pembelajaran daring dan siswa sulit mengerjakan soal-soal yang diberikan guru yang sedang tidak melakukan pengawasan secara langsung. Hal tersebut sesuai dengan pendapat Asmuni [20] yang mengatakan bahwa kendala pembelajaran daring adalah konten materi yang disampaikan secara daring belum tentu bisa dipahami semua peserta didik karena keterbatasan guru dalam mengontrol pembelajaran

Oleh karena itu, untuk meningkatkan kemampuan berpikir kritis matematis siswa pada materi segi empat diperlukan latihan secara terus menerus oleh siswa itu sendiri dalam menyelesaikan masalah-masalah yang berkaitan dengan materi tersebut. Selain melakukan latihan terus-menerus, siswa juga perlu mengembangkan kemampuan berpikirnya dengan terus memperbanyak informasi yang bukan hanya dari guru saat pembelajaran melaikan menfaatkan teknologi informasi di luar pembelajaran.

\section{Kesimpulan}

Dapat disimpulkan bahwa kemampuan berpikir kritis matematis siswa pada materi segi empat yang dilaksanakan dengan pembelajaran daring tergolong sedang dengan presentase $68,42 \%$. Hal ini ditunjukkan dengan adanya 23 responden hanya ada 5 siswa yang berada pada kategori tinggi, 14 siswa berada pada kategori sedang dan 4 siswa berada pada kategori rendah. Ditinjau dari masing-masing indikator kemampuan berpikir kritis siswa, diantaranya identifikasi masalah memperoleh presentase sebesar 78,74\%, analisis memperoleh presentase sebesar $71,74 \%$, sintesis memperoleh presentase $66,18 \%$, dan menarik kesimpulan dengan presentase sebesar $57,00 \%$. 


\section{Referensi}

[1] W. Wiryanto, "Proses Pembelajaran Matematika di Sekolah Dasar di Tengah Pandemi Covid-19," Jurnal Review Pendidikan Dasar: Jurnal Kajian Pendidikan dan Hasil Penelitian., Vol.6, No.2, 2020

[2] Maulana, Konsep Dasar Matematika dan Pengembangan Kemampuan Berpikir Kritis/Kreatif. Jakarta: UPI Sumedang Press, 2017.

[3] H. Sumarmo, Hard Skills dan Soft Skills Matematik Siswa. Bandung: PT Refika Aditama, 2017.

[4] W. Pertiwi. "Analisis Kemampuan Berpikir Kritis Matematis Peserta Didik SMK Pada Materi Matriks" Jurnal Pendidikan Tembusai, Vol. 2, No 3, pp 821-831, 2018.

[5] A. Sadikin, and A. Hamida, "Pembelajaran Daring di Tengah Wabah Covid-19," Jurnal Ilmiah Pendidikan., Vol. 6, No. 2, pp 214-224, 2020

[6] E. Hulukati, N. Achmad, and M. A. Bau, "Deskripsi Penggunaan Media E-Learning dalam Pembelajaran Matematika di Masa Pandemi Covid-19," Jambura J. Math. Educ., vol. 2, no. 1, pp. 21-27, Mar. 2021, doi: 10.34312/jmathedu.v2i1.10061.

[7] U. Verawardina, L. Asnur, and A. L. Lubis."Review Online Learning Facing The Covid-19 Outbreak," Talent Development and Excellence., Vo. 12 No. 3s, 2020.

[8] F. Suleang, N. Katili, and S. Zakiyah, "Analisis Kemandirian Belajar Siswa Melalui Pembelajaran Daring pada Mata Pelajaran Matematika," Euler J. Ilm. Mat. Sains dan Teknol., vol. 8, no. 1, pp. 29-35, Apr. 2021, doi: 10.34312/euler.v8i1.10392.

[9] A. W. Abdullah, N. Achmad, and N. C. Fahrudin, "Deskripsi Hasil Belajar Matematika Siswa Melalui Pembelajaran Daring pada Pokok Bahasan Bangun Ruang Sisi Datar," Euler J. Ilm. Mat. Sains dan Teknol., vol. 8, no. 2, pp. 36-41, Dec. 2020, doi: 10.34312/euler.v8i2.10324.

[10] R. D. Sasanti, "Pengajuan Masalah Berbantuan Edmodo Sebagai Upaya Meningkatkan Keaktifan Siswa di Era Pandemi COVID-19," Euler J. Ilm. Mat. Sains dan Teknol., vol. 8, no. 2, pp. 60-69, Dec. 2020, doi: 10.34312/euler.v8i2.10417.

[11] L. D. Herliandry, N. Nurhasanah, M.E. Suban, and Kuswanto, "Pembelajaran Pada Masa Pandemi Covid-19," Jurnal Teknologi Pendidikan., Vol.12, No. 1, 2020.

[12] Kusuma, and Hamidah. "Perbandingan Hasil Belajar Matematika Dengan Penggunaan Platform Whatsapp Group dan Wbinar Zoom Dalam Pembelajaran Jarak Jauh Pada Masa Pandemik Covid 19,”. Jurnal Ilmiah Pendidikan Matematika, Vol 5, No. 1, pp 97-106, 2020.

[13] I. Fithriyah, and C. Sa'dijah. Sisworo. "Analisis Kemampuan Berpikir Kritis Siswa Kelas IXD SMPN 17 MALANG," Konferensi Nasional Penelitian Matematika dan Pembelajaran (KNPMP 1), Vol. 1, No. 3, 2016

[14] W. Pertiwi. "Analisis Kemampuan Berpikir Kritis Matematis Peserta Didik SMK Pada Materi Matriks," Jurnal Pendidikan Tembusai, Vol. 2, No 4, pp. 793-801, 2018.

[15] T. Tresnawati, W. Hidayat, and E. E. Rohaeti, "Kemampuan Berpikir Kritis Matematis Dan Kepercayaan Diri Siswa SMA," Symmetry Pas. J. Res. Math. Learn. Educ., Dec. 2017, doi: 10.23969/symmetry.v2i2.616.

[16] P. Zakaria, A. Kaluku, and F. Rontos, "Analisis Kesulitan Guru Matematika dalam Menerapkan Proses Pembelajaran Jarak Jauh (Distance Learning)," Jambura J. Math. Educ., vol. 2, no. 1, pp. 1-14, Mar. 2021, doi: 10.34312/jmathedu.v2i1.10003.

[17] C. Barhomi. "The Effectiveness of Whatsapp Mobile Learning Activities Guided by Activity Theory on Students Knowledge Mangement," Contemporary Educational Technology, Vol 
6, No 3, pp 221-238, 2018

[18] S. Arikunto, Prosedur Penelitian, Edisi Revisi 6. Jakarta: Rineka Cipta, 2010.

[19] A. Syahbana, "Peningkatan Kemampuan Berpikir Kritis Matemats Siswa SMP Melalui Pendekatan Contextual Teaching and Learning,". Jurnal Edumatica, Vol. 2 No. 1, 2020.

[20] A. Asmuni, "Problematika Pembelajaran Daring di Masa Pandemi Covid-19 dan Solusi Pemecahannya,” J. Paedagogy, vol. 7, no. 4, p. 281, Oct. 2020, doi: 10.33394/jp.v7i4.2941. 